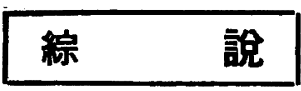

\title{
蛋白質の栄養価測定法について
}

On the Estimation of Nutritive value of Protein

神立誠

(Makoto Kandatsu)

Iはしがき

蛋白質の栄恶上の役㓶は熱量としては20\%以下である から、エネルギーを供給する栄素素ではなく，その㰌成

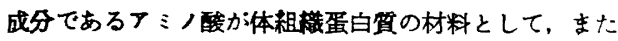

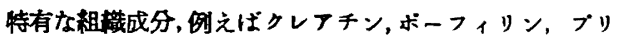
ン, ある盾のホルモン等の材料として用いられるためで

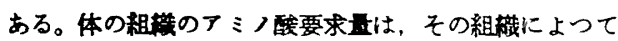
異る管であり，生理的状態か湾ればその粗機の合成能力 る努つてくると考えられるから，動物全体として見た場 合には蛋白質の要求量も变つてくる筈である。その著し い列は生長中の動物と，成長してしまつた動物の蛋白質 要求贯が異る事であつて，始娠，泌乳，産畉等の場合に 就てる同㥞である。また組㼄の蛋白質代謝は交り易いと い5点からあるアミノ酸か㳅足した場合には䇪素出納は 0 であり，体重は維持している場合です，ある特定の組 樴のアミノ酸合量が低下することがあり，1）各組織間に はそのアミ/酸に対する競合 (competition) がある。 即ち代謝回転の医的ておそい組機に久乏の症状か現われ るまでКは長い期間を必要とすることになり，短期間で は前に述へたように鉒素平皃を保つているからといって その蛋白侗が栄䅈上完全であるとは断定できない。換言

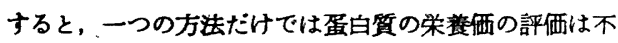
充分な場合があると考えられる。

また蛋白質の評価には例えばビタミンの評価等とは本 筧上異なつた点がある。ビタミンでは一時に，多くの場 合一つのビタミンを問题にして評洒寸ることができるけ れどす，蛋白質の場合には少なくとも必須である 9 10 種のアミノ酸の含量を問題にしなければならないし，又 アミノ酸相互のバランスの問題がある。

近時蛋白質栄意に関する研究が進んできたために，従 来の評価法は再検討され，またいくつかの新しい方法も 提唱されてきている。これらの方沠で評価された蛋白質 の栄意価は測定方法が異るから当然その価る異つてく る。

従つて，数種の方法を比教㮆討するためには標準蛋白 蚠を決める必要す生しててくると考えられる。
III蛋白質の評価法一一旧法

(a) 生長部験及び Protein Efficiency Ratio 幼白国に種々の蛋白質を与えてその成長に及ばす影翌

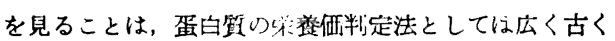
から用いられている Osborne 及び Mendel によつて創 始された方法であつて，この方法は更に発展させられて Protein efficiency ratio (P.E.R.) とい5概念にまとめ あげられた。2) Protein efficiency ratio=掑取蛋白質 $1 \mathrm{~g}$ 当りの体重增加 $\mathrm{g}$ 。

P.E. R. は食物中の蛋白質含量によつてその値か湾る ので一例えばカゼインでは12\%，ラクトアルブミンで は $7.9 \%$ で最大の值をとる— $10 \%$ の含量で習慣上その 値を求めている。蛋白質の栄鉒価か高ければ高い程, 食 物中の蛋白質含量は低い点で P.E.R.は最高值をとる。

この事実は最適の効率を示寸ために, 蛋白質中のアミ ノ酸は適当なバランスが必要であることを意味している

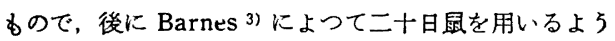
に改良されている。

P.E.R. そのものの内容に就ては Hegsted4) は多数の 実験をして体重の增加割合に殆んど完全に平行な值であ るから，別に体重增加そのものを比較する以上の内容は 持ち得ないことを述く，従つて每日の飼料掑取量は測る 必要がないといつている。

(b) 窒素出納法

(i) 生 物 価

蛋白質の評佂法として古く(1909) Thomasにより成 人に関して唱えられ, 後 Mitchell により改良され, 生 長中の白最に就て成長と維持に対する要求量を含むよ5 になつた周知の方法で空素の出納から求める方法であ る。

$$
\begin{aligned}
& \text { 生物価 }=\frac{\text { 体内に保留された咥素量 }}{\text { 吸収された窒素量 }} \times 100 \\
& =\text { 吸収された窒素量一(蛋白給与時の尿中窒素量 }
\end{aligned}
$$

この生物価とい5概念のもつている意味は吸収された 
蛋白質 100 部に対する動物体内での体蛋白筫の消耗を補 5制合であつて， P.E.R. よりはその内容がより正確に 規定されていると考えられる。測定の呏際に当つては動 物飼育, 萁尿の分離, 窒素の定量等に可成の困難があり, また理論上では後述する endogenous nitrogen の間題 々 metabolic fecal nitrogen (M.F.N.) の血の間題, 即ち無蛋白食のときの M.F.N. 量と供試食の场合の量 とが等しいか否かとい5点か疑問のまま残されている。 この点は高濃度の重㱖素化台物か得られるよ5になつて きたから実験的に解決できるよ5に思われる。

蛋白質の生物価には消化吸収率は無関倸であるが，こ れでは利用する場合に不便なので，消化率更に食品中の 蛋白質含量までを考慮した Net protein value を用い ることがある。

Net protein value $=$ 虽白質含量 $(\%)$ $\times$ 消化吸収率 $(\%) \times$ 生物価(\%)

(ii) 内生窒素 (Endogenous nitrogen)

O. Folin ${ }^{5)}$ が多数の人間を用いてて食物中の垐素及び尿 中の空素化台物を分別定量した結果をまとめて蛋白質の 代謝型式に二つ(Endogenous及びExogenous)あること を提唱したのは1905年で，その後長い間この説が充分検 討されたか否かは余り明らかではないか，実際上の説明 には大した破綻をみせずに用いられてきた。Folinの説は 蛋白質代謝には二つ型式があつて，一つは食物中の蛋白 質の供給割合によつて直接左右され，異化される型式で Exogenous と呼び，尿中の尿素量によつて代表される。 他の一つは Endogenous と名つけけられもので,第一義 的には種々の生理的活性によつて左右されるもので, 蛋 白質の共給割台によつては全くではないか，影響される こと少い型式であつて，尿中のクレテチニン及び尿酸含 量によつて代表されるものである。尿中尿素量が蛋白質 の供給割合によつて激しく変動すること及び尿中クレア チニン及び尿酸含量か殆んどー定であることはFolinの 後多数の研究者によつて確認されている。1942年になつ てR.Schönheimer ${ }^{6)}$ は重空素アミノ酸を等素平海の状態 にある白爵に与えて, その重空素が体蛋白質にも incorporate された事実を基にして蛋白質代謝は Folin の説 のよ5に二つの型式に分れているものではなく，一つの pool があつて，そこに食物からの蛋白質む入つていき 体組織の蛋白質は pool から材料をとつて蛋白質中の登 素を交換（生成及び分解）しているという“Dynamic state”にあるとい5説を唱え, 現在圧倒的多くの支持 を得ており，特に生化学関係の研究者は海々としてこの 説を支持しているといつても過言ではないであろ5。 然し後者の説に反対するすのす絶無ではない。その著 しい例は蛋白筫の生物質を今日まで発展させた Block
や Michell1)8) の反対である。その要点は白聂及び豚の

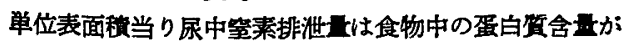
ある䈥囲で变化しても単位表面程当り吸収量をとれば直 楾関俰になり，この範团は蛋白鿓の生物価によつてき まる。例えば卵蛋白では $55 \mathrm{mgN} / 100 \mathrm{~cm}^{2}$ であり，牛肉蛋 白では $85 \mathrm{mgN} / 100 \mathrm{~cm}^{2}$ である。またこの直楾が尿中窒 素排泄五の軸をきる点は蛋白筫 0 とした時に尿中排泄! の軸をきる点と同一であるから Endogenous nitrogen は略一定であるとい5ことを考えないでは説明し難いと いろ点である。

又数人の同位元素を用いた荚駼結果からも，絶食中の 動物にはアミノ酸ブールに関倸のある二つの䝪藏所があ つて,その一つは組樴のアミノ酸と速かに反応するが,他 の一つは不可逆的に水㻮を受けるよ5なるのであつて， 同位元素を用いての実験結果も endogenous metabolismの性筫を明らかにしたすのであると述べている。 昨年の醭素化学シンボジムに於ても R. J. Block は 同样の意見を発表している。

蛋白筫の栄価を評定するとい5ことそれ自身は，吾 々のためにする主として技術的な問題である。

然しそれもその根底にある理論なしには正確さを望み 得ない状態にをで立ち到つていることをこの論争が示し ているよ5に思われる。

一方に Dynamic state の見晖は多くの生化学者に受 け入れられ，栄爰を基点とした研究者には二元説を主張 していることは、ここに同一の現象を研究する二つの立 場の者の吻合点の一つを見出したとるいえよ5。将来の 研究に期待したい点であり, Endogenous nitrogen は 蛋白貿の最少必要要を決定するためにも一首の研究が必 要と思われる。蛋白筫栄㓌に関する諸説に就ては他日稿 を改めて述へてみたいと考えている。

(iii) Nitrogen balance index

Allison らによると成犬は管理をよくすると所謂 Endogenous nitrogen 吾は可成よく一定となるから等素 出納に対して吸収等素量を画くと直楾となりこの線は 公素出納か（一)から僅かに(+)の処で直線性が強い。徒 つて㘹素出納 0 附近の值は信頼し得る值とみなされる。 鈭素出納: $y$, 吸収跮素量: $\boldsymbol{x}$ とすると直線は

$y=a+b x$ となる。 $b$ は直線の傾斜角の tangent K 相当するすので, 生物価 100 のすのであれば $1 \mathrm{~g}$ 吸収す れば窒素出納は $1 \mathrm{~g}$ 增加し， $b$ は 1 となり，傾斜角は $45^{\circ}$ となる。生物価が 100 より小さければ bは1より小 さくなる。この $b$ を nitrogen balance index といつ て蛋白留の価值判定の一つに用いられ100をかけると生 物価になる。これは前述の生物価の場合のよ5に無蛋白 食の時の窒素排泄一をを求めなくてもよいので，この難点 
はさけられるが，出納試験であることは变りがないので 長期に亘る点, 及び endogenous nitrogen にその根底 をおいているからこれが仲々に一定になり難いために 跿局直楾になり難いとい5久点がある。

以上の二方法の改良法 ${ }^{10)}$ すいうべきすのに，全卵蛋 白資は殆んど 100 に近い生物価をるつている事は多数の

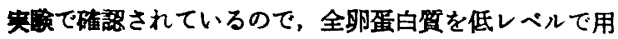
いて endogenous nitrogen 量を測つて，この值を用い て他の蛋白質の生物価を求的るといら方法も考案されて いる。

\section{III 蛋白質再生法}

成長した動物を一定期間無蛋白食で飼 5 と体蛋白質は 分解されるか，その時に動き易い肝豚や血蛋白筫は減 少共が大きい。この槏な状態にしておいて供訊動物に蛋

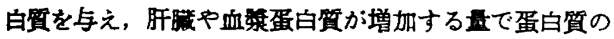
栄端価を判定しよ5とする方法で，必須アミノ酸要求量 の湌討に用いられたか，有名なアミノ酸混合物を用い た Rose の実駼結果とよく一致した結果か得られた。そ のまとめたものを第 1 表11)に揭げる。

第1表 白最の生長，再生，䊒持に対する必要量

\begin{tabular}{|c|c|c|c|c|c|c|}
\hline & 再 生 & 比 & 体重維持 & 比 & 生長 & 比 \\
\hline & $\mathrm{mg} / \mathrm{\tau} / \mathrm{\theta}$ & & $\mathrm{mg} / 100 \mathrm{~cm}^{2}$ & & $\%$ & \\
\hline トワプトファン & 14. & 1 & l敫 2.2 & 1 & 0.2 & 1 \\
\hline & 45 & 3.1 & 6.0 & 2.7 & 0.7 & 3.5 \\
\hline -1 1 > & 72.5 & 5 & 8.0 & 3.6 & 0.8 & 4 \\
\hline インロイシン & 61 & 4.2 & 13.7 & 6.2 & 0.5 & 2.5 \\
\hline メチオ $=$ ע & 39 & 2.7 & 7.3 & 3.3 & 0.6 & 3 \\
\hline$\pi v \pi=y$ & 43 & 3.0 & 5.3 & 2.4 & 0.5 & 2.5 \\
\hline ワ チ & 58 & 4.0 & 4.5 & 2.0 & 1.0 & 5 \\
\hline ヒスチチע & 21.5 & 1.4 & 2.2 & 1.0 & 0.4 & 2 \\
\hline ベ & 51 & 3.5 & 10.0 & 4.5 & 0.7 & 3.5 \\
\hline
\end{tabular}

これら9種の必須アミノ酸相互の比は全卵蛋白質中の 比によく似ている。また Rose の生長試験の結果とを対 比すると著しく異るのはリヂンであつて，再生法には近 いか泍重維持の場台よりは可成大きい。

これはりデンの生理作用の一面をはつきり現わしたも のとして興味梁く感じられる。

本法に対しては無蛋白食飼育の期間, 次いで蛋白食給 与の方法, 蛋白質のレデル等に就て詳細な検討が行われ ており，その条件下で実験を行5必要がある。以上の実 物物は白最であが，肝䑏の窒素岳の增減では判定は 困難であるとい5報告12)か泏されている。

\section{IV アミノ酸含量比較法}

全卵蛋白翼の生物価は 100 K近いことから Block 及
びMitchell ${ }^{13)}$ らはアミノ酸含量の点で制限因子となつ ているある蛋白質のアミノ酸含量を全卵蛋白質のそのア ミノ酸含量に対する\%として現わすとその蛋白質の生物 筫との間には第 1 园のよ5な強い相関のあることを見出 した。

第 1 因

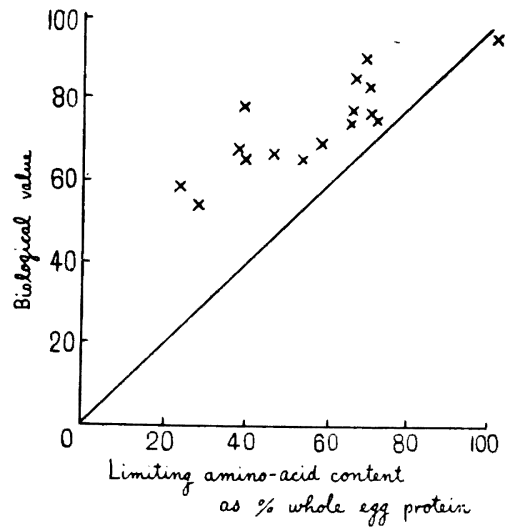

その式は $y$ : 生物価, $x$ : 必須アミノ酸の必要量と比 效した不足の\%

$$
y=102-0.634 x
$$

となる。この式によりある蛋白質の必須了ミノ酸含量を 知れば，その5ちの $x$ に最大の值を代入すると生物価 が求められる。

第 1 汶からす分るよ5に、こ5して求めた值は少し高 くでる，その理由は全卵蛋白質の生物価は 96 であるの を 100 としたためであるから，十数種の蛋白質の必須ア ミノ酸含量に 100 生物価を乗じてアミノ酸含量を算出 し，それを比較して最低题を集めて，ideal proteinを 考え，これを全畉蛋白貿の代りにすると，その直楾よ り求められる值は前の直線よりむよく当てはまるよ5に なる。第 2 表に ideal protein の求め方をあげる。

第 2 表

\begin{tabular}{|c|c|c|c|c|c|c|c|}
\hline 生蛋白源 & $\begin{array}{c}\text { 全卵 } \\
90\end{array}$ & $\begin{array}{c}\text { 牛乳 } \\
90\end{array}$ & $\begin{array}{c}\text { 白米 } \\
75\end{array}$ & $\begin{array}{c}\text { 牛 } \\
\text { 心嵗 } \\
74\end{array}$ & \begin{tabular}{|c} 
カZ \\
$1 ン$ \\
69
\end{tabular} & \begin{tabular}{|l} 
落花 \\
生 \\
58
\end{tabular} & $\begin{array}{c}\text { ideal } \\
\text { pro- } \\
\text { tein } \\
100 \\
\end{array}$ \\
\hline Arg & 6.7 & 4.7 & 9.6 & 9.9 & 5.1 & 15.8 & 4.7 \\
\hline Hist & 2.2 & 2.9 & 2.0 & 3.6 & 4.4 & 3.6 & 2.0 \\
\hline Lys & 7.6 & 8.3 & 4.3 & 9.9 & 11.4 & 5.1 & 4.3 \\
\hline Trypt & 1.6 & 1.8 & 1.7 & 1.9 & 1.7 & 1.7 & 1.6 \\
\hline Tyr & 4.7 & 5.8 & 7.5 & 5.9 & 10.0 & 7.5 & 4.7 \\
\hline $\mathrm{PhAl}$ & 6.6 & 6.3 & 8.9 & 6.8 & 8.1 & 9.1 & 6.3 \\
\hline 塾 & 11.3 & 12.1 & 16.4 & 12.7 & 18.1 & 16.6 & 11.3 \\
\hline
\end{tabular}




\begin{tabular}{l|r|r|r|r|r|r|r}
\hline \multicolumn{1}{l}{ Cyst } & 2.5 & 1.1 & 1.9 & 1.6 & 0.4 & 2.6 & 0.4 \\
Meth & 4.3 & 3.7 & 4.5 & 4.3 & 2.0 & 5.1 & 2.0 \\
\hline \multicolumn{1}{c|}{ 計 } & 6.8 & 4.8 & 6.4 & 5.9 & 5.5 & 4.6 & 4.6 \\
\hline Threo & 5.1 & 5.0 & 5.5 & 6.3 & 6.0 & 2.6 & 2.6 \\
Lenc & 9.6 & 12.4 & 12.0 & 11.2 & 11.1 & 11.9 & 9.6 \\
Isolenc & 8.3 & 9.4 & 7.1 & 6.9 & 9.4 & 5.1 & 5.1 \\
Val & 7.6 & 9.2 & 8.4 & 8.4 & 9.7 & 11.4 & 7.6 \\
\hline
\end{tabular}

本法は蛋白質中のアミノ酸の定量法が急速に正確にな つてきている点及び各種の動物に対するマミノ酸の要求 量も，次第に正磪になつて行く点から信頼性を增して行 くと考えられる。一方，前にす述へたよ５に蛋白筫栄笭 に関する基礎知識は，この方法によつて得た結果をその まま信頼できる程にはまた進歩していないと惩められる から，動物による検定はなお梳けて行く必要があるであ ろ5。

\section{V 酵素活性による方法}

前の組織再生法の項で述べたように，肝臟の重量は蛋 白質栄養の状態によつて大きく变化するか，更にその中

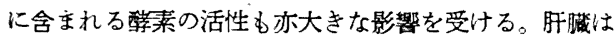
醇素の集団そのもののようなものであつて，多数の醉素 を含んでいるか，蛋白質栄䓹汇敏感なるのとそうでない ものとがある。前者には Xanthin oxidase, Arginase 等が代表的なるので，就中前者は非常に食物中の蛋白質 (必須アミノ酸含量) に敏感に反応寸るので，この活性 を測定し 蛋白質の栄養価を比較しょうとする方法であ る。14）その方法の概略は白鼠数匹を一群として，一種の 蛋白質に就てはその含量のレベルをかえて給与するか， 一定の含量で各種の蛋白質を与えるかして9〜10日飼育 後，屠殺，肝臟をとりたし秤最，一部に就て窒素含盟を 測定し，他方その木モジネートについてワールブルグ㛟 仕計を用いて，ヒボキサンチンを加えてこれがキサンチ ンに酸化される際の酸素の吸収量を求め, 酻素活性を $\mathrm{mlO}_{2} /$ 時間/新鮮肝g で比較する。同梯な 実験は生長中 の白瓦です行うことができる。本法は蛋白質の評価法と しては醇素活性か䣼量に, 即ち特定の蛋白質の生成量 に比例すると凡そ考えて差支えないから，体重变化等よ りも特異性の強いもので，蛋白質の質のわずかな差も認 めることができる。

例えば15)必須アミノ酸 (E.A.A.) と不欠アミノ酸 (N. E.A.) との関係を追究した実験では

N.E.A. 混合物 $\begin{cases}\text { Glycine } 2 & \text { DL-Alanine } 8.9 \\ \text { DL-Serine 5 } & \text { L-Cystine } 4.5 \\ \text { L-Tyrosine 13.4 } & \text { L-Glutamic }\end{cases}$ acid 66.5

の混合物をつくり，これを E.A.A.混合物 ${ }^{16)}$ に加えて他

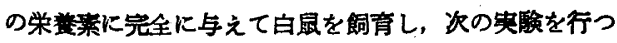
た。

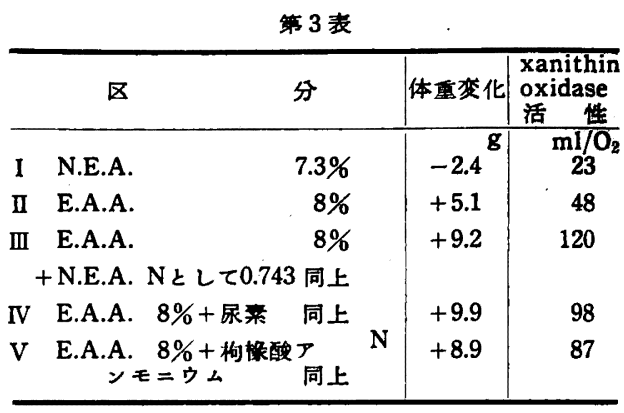

この結果は E.A.A.に N.E.A. 枸格酸アンモニウム, 尿素等を加えると明らかに生長がよなること示してお り，又N.E.A. 添加の方か:尿素添加の場合より，体重增 加とは反対に xanithin oxidase 活性か滈いのは N. E. A. 中に Cyst. が含まれているためであると説明されて いる。

蛋白質の評価と関連し，蛋白質栄意の研究に体内酵素 活性の增减を指標とする研究は漱く盛んになり，本邦で る告田教授尚らの一連の研究がある。生化学における蛋 白貿生成の研究か盛んに行われていることを考えれば， この方向は蛋白筫栄研究の一つの新しい分野といえる だろっこの点栄食と生化学とをつなぐ一つの交叉点 として,一つの境界領域の開拓として今後に期待した w。

\section{引用文 萠}

1) R. B. Fischer: Protein metabolism, 166 (1954)

2) T.B. Osborne, L. B. Mendel et al : J. Biol. Chem., 37, 223 (1919)

3) D. K. Bosshendt, L.C. Ydse et al : J. Nutrition, 31, 23 (1946)

4) D. M. Hegsted, J. Warcester : J. Nutrition, 33, 685 (1947)

5) O. Folin: Am.J. Physiol, 13, 117 (1905)

6) R. Schönheimer: The dynamic state of body constituents (1942)

7) R. J. Block, H. H. Mitchell : Nutrition absts \& Rev., 16, 249 (1946-47)

8) H. H. Mitchell : J. Nutrition, 55, 193(1955)

9) J. B. Allison, J. A. Anderson: J. Nutrition, 29, 413 (1945)

10) E. E. Sumner, H. B. Pierce et al : J. Nutri- 
tion, 16, 37 (1938)

11) A. A. Albanese : Protein \& amino acid requiremets of mammals, 45 (1950)

12）森本宏・林弥太祁：晨技研竍 G., 6, 131 (1953)

13) R. J. Block, H. H. Mitchell : Nutrition absts. \& Rev., 16, $249^{\prime}(1946-47)$

14) G. Litwack, J. N. Williams et al : J. Nutrition, 47, 299 (1952)

15）同上 : J. Biol. Chem., 201, 261 (1953)
16) H. A. Lardy, G. Feldolt : J. Boil. Chem., 186,85 (1956)

17）村松敬一郎・芦田淳等：日典化殸，28，984 (1954), 同上, 29, 725 (1955) 同上 31 $603,607,(1957)$

(東京大学農学部農芸化学科)

タルコースオキシターゼによるビールの安定化

ビール中に溶存する醉素によつてビールの品質低下か： 起るので各喠の対策がなされているか，どれす現在の所 十分とは言えない。この目的にグルコースオキシダーゼ 一カタラーゼ忞を使用すると添加直後から，消费される まで良好な結果を得ることができた。すなわち，この醅 素䒺による反忘は

$$
\begin{aligned}
& 2 \mathrm{H}_{2} \mathrm{O}+2 \text { glucose }+2 \mathrm{O}_{2} \frac{\text { glucose }}{\text { oxidase }} \rightarrow 2 \text { gluconic acid } \\
& +2 \mathrm{H}_{2} \mathrm{O}_{2}
\end{aligned}
$$

であり，隇菌したビールに於ても，普通用いられる隇菌 温度 $\left(60^{\circ} \mathrm{C}\right)$ では，䤃素活性の娍少は僅少であり，醉素 処理したビールは，数カ月間新鮮さを保つことができ又 娍菌しない生ビールの場合にも, 低温保存しなくとも数 週間保存することでできた。

Use of Glucose Oxidase to stabilize Beer by D. W. Ohlmeyer: Food Technology, 11, 503-507 (1957)

（福場）

\section{家鬼筋肉中のミオキナーセの精製之諸性算}

この研究は，醀の SH 基の諸性筫と加知に対する安 定性についてなされた。

用いた醇素は，家免の筋肉を冷却して，婏いた後，3 時間流水中にて，更に20倍量の水にて 6 時間透析し，こ の透析抽出物は, $\mathrm{NaHCO}_{3}$ 水浴液にて, $\mathrm{pH} 6.5$ とし， プロパールを濑次加え，40\%にする。沈浅を兑心分離

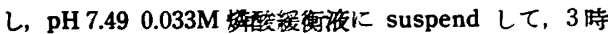
間透析，池影を冾水に suspend し，2N-HClにて pH 2 とし，5M-NaCl にて処理後，2N-NaOH にて pH6.5 とすると醭素は上洨液中に安定化する。これを橉酸カル シウム：粉末鯂紙 $(1: 4)$ のカラムにて，クロマトを行 い, 部素活性部を集め, $\left(\mathrm{NH}_{4}\right)_{2} \mathrm{SO}_{4}$ にて分別し, 0.65 0.85 飽和で沈影する部分を $25,000 \mathrm{~g}$ にて薏心分離し， $0.2 \mathrm{M}-\mathrm{NaCl}$ に溶かし，ボリェチレン容器に眝える。 かくして得たミオキナーゼの性質は次の如くである。 用いた酻夜は，電気泳動から見て単一であり，超遗 心分離によつてす単一と認められ，等電点は $\mathrm{pH} 4.3$ で ある。又䣼素の最大活性は， $\mathrm{pH} 7.5$ にあり，分子量は 超遠心により 21,600で，1 分子中に SH 基 2 コを舍むこ
とが，滴定により湘定された。沈降係数 $\mathrm{S}_{20}$ (水溶淮) は 1,7×10-13である。又超遠心によつて SH 基の可逆的

酸化は分子量に变化を与えないことが認められた。

反応は $\mathrm{pH} 7 \sim 8$ に於ては， $\mathrm{pH}$ が低いはど $2 \mathrm{ADP} \rightleftarrows$ $\mathrm{ATP}+\mathrm{AMP}$ の右へ傾く。

ミオキナーゼは，酸化されると活性を失5が、システ インを与えると復活する。酸中で加熱すると, 活性を低 下せしめるがシステインを添加すると, 活性山相当に現 われる。

これはまず $\mathrm{SH}$ 基の酸化 (可逆的) 次いで酸素の不可 逆的不活性化又は变性を引き起すと思われる。又酸素は ガラス容器に保存すると失活し，セロファンで透析して む失活する。この失活はシステインによつてす完全には 復活せず,ガラスの場合に特にひどい。

The purification and properties of rabbit muscle myokinase.

O. H. Callaghan: Biochem. J., 67, 651 (1957)

(五十嵐) 